\title{
THE GREAT GEOFFREY BURNSTOCK: A PASSION FOR DISCOVERY AND EMPATHY
}

Geoffrey Burnstock was born on 10 May 1929 into a working-class Jewish family in West London, one of two children of the family. He grew up in Ealing, and during the Second World War attended Greenford county grammar school. He took further science courses at Kingston College of Technology after his national service, but was unable to get into medical school as he had wished. Instead he won a place at King's College London to read zoology. His father having died, Geoffrey spent his weekends working in a graveyard to support his mother.

Burnstock began a PhD at King's College London on the nervous control of gut motility in fish, fascinated by the fact that goldfish eat all the time. He successfully completed his $\mathrm{PhD}$ thesis after asking one eminent neurophysiologist at University College London to take over as his supervisor in his final year. At University College London (UCL) he met Nomi Hirschfeld, a PhD student in cell biology from New Zealand, and they married in 1957. He moved to the University of Melbourne as a senior lecturer in 1959, later becoming Head of Department of Zoology.

In 1975 Burnstock returned to UCL as Head of the Department of Anatomy and Developmental Biology. He led a large research group, with many overseas visitors, all fired by his passion for discovery. Hence, the Department consistently achieved top rankings under his leadership. He was elected a fellow of the Royal Society in 1986 and received many other honours.

Burnstock stepped down as Head of department in 1997, and UCL moved his research group to the Royal Free Hospital School of Medicine, from center downtown to Hampstead area of North London of London. Until 2004 he ran the Autonomic Neuroscience Institute,

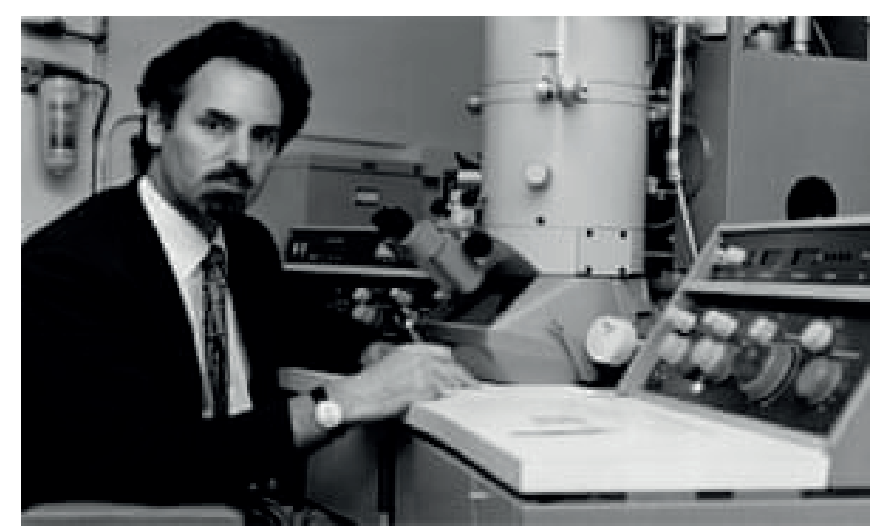

thereafter serving as its President and continuing his research collaborations and lecturing. Science was both his passion and his pleasure, and he never stopped thinking of new research ideas.

Geoffrey Burnstock started with an interest in the nerves that control vascular and intenstinal smooth muscles of laboratory animals, and discovered a completely unexpected and ubiquitous signalling system that plays a role in nociception, blood clotting, immunity and in the pathogenesis and therapy of cardiovascular diseases, cancer, Parkinson's disease, Alzheimer's disease, just to list several of them. As self-described "oddball", he "transformed" the energy supplier adenosine triphosphate (ATP) and its derivatives into signaling molecules. This was a paradigm shift, indeed. In 1972 Geoffrey Burnstock introduced the term "purinergic" transmission for this new phenomenon. This is non-adrenergic, non-cholinergic (NANC) neurotransmitter, a form of extracellular signalling mediated by purine nucleotides and nucleosides such as adenosine and ATP. Which he identified after observing the cellular responses in a number of systems exposed to the presence of cholinergic 
and adrenergic blockers. It involves the activation of purinergic receptors, most of them being G-protein-coupled receptors, that mediate various physiological functions as a response to ligation with ATP or adenosine.

Neophobia is often accompanied scientists' minds. It was the case with Burnstock's purinergic signalling concept too: it met with criticism, since ATP is an ubiquitous intracellular energy source so it seemed unlogical that cells might also actively release it as a signaling molecule. After years of scepticism, however, the concept was gradually accepted by the scientific community. Today, purinergic signalling is no longer considered to be confined to neurotransmission, but is regarded as a general intercellular communication system of many human organs. The purinergic signalling system consists of ATP, adenosine, uridine triphosphate (UTP) and uridine diphosphate (UDP), three distinct classes of purinergic receptors, known as $\mathrm{P} 1, \mathrm{P} 2 \mathrm{X}$, and $\mathrm{P} 2 \mathrm{Y}$ receptors, and enzymes responsible for the synthesis, release, and extracellular breakdown of ATP to adenosine. After the establishment of the Purine Club back in the 1990s, numerous Purine Club have been found around the world (1). Burnstock has been the founder of journal, Purinergic Signalling.

In 2017 Burnstock and his wife Nomi moved back to Melbourne, where he was an Honorary Professor at Melbourne University. In 2018 he was made a Companion of the Order of Australia. Geoffrey Burnstock died at age of 91 on 2 June 2020 . He is survived by Nomi, his daughters, Aviva, Tammy and Dina, and seven grandchildren.

Professor Burnstock was an extraordinary human being, always eager to collaborate and share data. He was known for his enthusiasm, empathy and ability to motivate young scientists and promote their careers. The number of obituaries and messages honouring Geoff's memory that have been published in both scientific journals and public media throughout the world since last June indicates that many people are clearly affected by his death (1).

\section{NOBEL INJUSTICES CONTINUE}

Why the Great Geoffrey Burnstock did not receive the Nobel Prize in Physiology or Medicine at least in 2019? Such an injustice was also applied to other scholars, for example, the Romanians Victor Babes in 1901 - for vaccines, Nicolae Paulescu in 1923 - for the discovery of insulin, and Gheorghe Benga in 2003 - for aquaporins, molecules that build up the water channels of the cell, and to Honduran-British pharmacologist Salvador Moncada in 1998 - for the multifunctional activity of nitric oxide (NO).

I met Geoffrey Burnstock for the first time during the Heidelberg Symposium on Vascular Smooth Muscle in Atherogenesis held in October 1973 in Gemany. In 19911992, as an Wellcome Trust Research Fellow, he was one of my Host Scientists at both Royal Free Hospital School of Medicine and UCL.

Professor Burnstock was the most prolific publisher in biomedical sciences, having 1275 articles, according to PubMed, 8 December 2020. He was the highly cited scientists in biomedicine, having more than 60000 citations, and an h-index of more than 120. Geoffrey Burnstock was a Great Scientists, indeed.

\section{On behalf of the Editors of Biomedical Reviews, the Bulgarian Society for Cell Biology, and the International Society of Brain-and-Heart Friends,}

George N. Chaldakov

1. Maria P Abbracchio. The history of the Purine Club: a tribute to Prof. Geoffrey Burnstock. Purinergic Signal 2020;1-8. DOI:10.1007/s11302-020-09749-4 